УДК: 631.1

\title{
UKRAINE: A LAND OF ECONOMIC PROBLEMS OR OPPORTUNITIES
}

\author{
K. Omelchenko, O. Solomka \\ National University of Food Technologies
}

\begin{tabular}{l}
\multicolumn{1}{c}{ Key words: } \\
Ukraine's economy \\
Economic indicators \\
Growth \\
Gross Domestic Product \\
Investment \\
Agriculture \\
Opportunity \\
\hline
\end{tabular}

Article history:

Received 15.11.2018

Received in revised form

06.12.2018

Accepted 21.12.2018

Corresponding author:

K. Omelchenko

E-mail:

npnuht@ukr.net

\begin{abstract}
The article deals with the main economic advantages of the country and its additional opportunities on the path to economic stability and development. The proposed analysis of the main macroeconomic indicators, namely: gross domestic product, unemployment rate, interest rate analysis, production, imports and exports, consumption, etc., in order to identify additional opportunities and certain problem areas. According to the analysis, it can be noted that at present the country is in an unstable state. According to the analysis, certain indicators deteriorate from 2013 to 2017 inclusive. Particularly negative factor here can be considered a constant decline in population and worsening economic performance. On the basis of the study, the forecast of some indicators for 2019 is proposed quarterly and by 2020 inclusive, which shows that the economic situation in the country will gradually stabilize.

Particularly, improvements will be made in the area of production and consumption by increasing wages, subject to the sustainability of tax payments and fees. It is also worth noting that, according to the forecast, inflation will somewhat decrease and in 2020 will amount to $5.2 \%$. Also, the amount of public debt will decrease somewhat.

The purpose of the article is to identify economic opportunities of the country with the goal of their optimization and use in the future to achieve economic growth. The main object of the research is the state and its separate units. According to the results of the conducted research, it is possible to optimize the use of certain resources of Ukraine in order to achieve its economic stability and development, for example, use of solar energy, reform of the agro-industrial complex, improvement of the investment climate of the country and the legislative framework in this direction, use of developed infrastructure of the country, etc.
\end{abstract}

DOI: $10.24263 / 2225-2924-2018-24-6-11$ 


\section{УКРАÏНА: КРАÏНА ЕКОНОМІЧНИХ ПРОБЛЕМ ЧИ МОЖЛИВОСТЕЙ}

\section{К.Ю. Омельченко, О.М. Соломка}

Національний університет харчових технологій

У статті розглянуто основні економічні переваги краӥни та ї̈ додаткові можливості на шляху до економічної стабільності та розвитку. Запропоновано аналіз основних макроекономічних показників, а саме: валового внутрішнього продукту, рівня безробіття, аналіз відсоткової ставки, виробниитва продукиії, імпорту та експорту, споживання тощо з метою виявлення додаткових можливостей і певних проблемних місиь. Згідно з аналізом можна відмітити, що на сьогодні країна знаходиться у нестабільному стані. Деякі показники погіршуються, починаючи з 2013 року і до 2017 року включно. Особливо негативним фактором можна вважати постійне зниження кількості населення та погіршення економічних показників.

На основі дослідження запропоновано прогноз деяких показників для 2019 року поквартально і до 2020 року включно, з якого видно, що економічна ситуація в країні поступово буде стабілізуватися. Особливо покращення відбудеться у сфері виробництва та споживання за рахунок збільшення заробітної плати за умови сталості податкових платежів $і$ зборів. Також варто відмітити, що за результатами прогнозу інфляція дещо зменшиться і у 2020 році становитиме 5,2\%. Також дещо скоротиться сума державного боргу.

Метою статті є виявлення економічних можливостей крайни, що дасть змогу їх оптимізувати та використати в майбутньому для досягнення економічного зростання. Основним об'єктом дослідження статті виступає держава та ї̈ окремі підрозділи. За результатами проведених досліджень $\epsilon$ можливість оптимізувати використання певних ресурсів України з метою досягнення ї̈ економічної стабільності та розвитку, наприклад, використання сонячної енергії, реформування агропромислового комплексу, покращення інвестиційного клімату країни та законодавчої бази в цьому напрямку, використання розвинутої інфраструктури країни тощо.

Ключові слова: економіка України, економічні індикатори, зростання, валовий внутрішній продукт, інвестиції, аграрна промисловість, можливості.

Formulation of the problem. Ukraine is a potentially rich country that realizes itself and is perceived from the outside as a political and economic power similar to other countries. Among the former republics of the USSR, Ukraine inherited one of the best sets of initial resources. Before independence, the economy of the Ukrainian USSR was playing a main role in the economy of the USSR [1].

But while the military aspects of the conflict have dominated the headlines, the real battle for Ukraine's future has always been elsewhere.

It rests on the ability of the country to restore stability and prosperity even as its territorial integrity is being brutally compromised. 
In our opinion, above all, it is the economic stability of the country, which is provided not only by various capacities, but also by the ability of political forces to properly manage resources. In other words, it is the ability of a country to withstand economic or other threats based on its potential, reserves, and so on.

Analysis of recent researches and publications. Recently, much attention was paid to the study topic. Results of the study can be found on the Internet, which covered not only political articles on the subject, but the results of the investigations of the scientists.

The purpose of the article is to identify economic opportunities of the country with the goal of their optimization and use in the future to achieve economic growth.

Statement of key research results. So let's initialize the general situation in Ukraine in order to understand what threats and opportunities the country has.

Ukraine's economic freedom score is 51.9, making its economy the 150th freest in the 2018 Index. Its overall score has increased by 3.8 points, reflecting improvements in eight of the 12 economic freedom indicators and particularly significant improvements in monetary freedom and investment freedom. Ukraine is ranked last among 44 countries in the Europe region, and its overall score is below the regional and world averages.

Now let's turn to a more detailed analysis of the economic situation in the country by separate macro indicators.

First of all, we want to admit, that Ukraine's economy grew by $2.5 \%$ in 2017 , the second year of modest growth, according to the World Bank's. Growth in manufacturing, services, and construction was robust, but weaknesses in the agriculture and mining sectors, together with delays in key reforms to further strengthen investor confidence contributed to the modest overall growth performance [2].

The main economic indicators of the country for 2013-2017 years are shown in Table 1 [3].

Table 1. Ukraine Economy Data

\begin{tabular}{|c|c|c|c|c|c|c|c|}
\hline № & Indicator & 2013 & 2014 & 2015 & 2016 & 2017 & $\begin{array}{c}\text { Absolute } \\
\text { deviation } \\
17 / 16\end{array}$ \\
\hline 1 & 2 & 3 & 4 & 5 & 6 & 7 & 8 \\
\hline 1 & Population (ml) & 45.2 & 42.8 & 42.6 & 42.4 & 42.3 & -0.1 \\
\hline 2 & GDP per capita (USD) & 3.98 & 3.06 & 2.06 & 2.18 & 2.68 & +0.5 \\
\hline 3 & $\begin{array}{c}\text { Economic Growth (GDP, annual } \\
\text { variation in \%) }\end{array}$ & 0.0 & -6.6 & -9.8 & 2.4 & 2.5 & +0.1 \\
\hline 4 & Consumption (annual in \%) & 6.9 & -8.3 & -20.7 & 2.1 & 7.8 & +5.7 \\
\hline 5 & Investment (annual variation in \%) & -8.4 & -24.0 & -9.2 & 20.4 & 18.2 & -2.2 \\
\hline 6 & $\begin{array}{c}\text { Industrial production (annual } \\
\text { variation in \%) }\end{array}$ & -4.3 & -10.1 & -13.0 & 2.8 & 0.4 & +2.4 \\
\hline 7 & Unemployment rate & 7.2 & 9.3 & 9.1 & 9.4 & 9.5 & +0.1 \\
\hline 8 & Fiscal balance (\% of GDP) & -4.3 & -4.5 & -1.6 & -2.3 & -1.4 & +0.1 \\
\hline 9 & Public debt (\% of GDP) & 39.9 & 69.4 & 79.1 & 80.9 & 71.8 & -9.1 \\
\hline
\end{tabular}


Continuation of the table 1

\begin{tabular}{|c|c|c|c|c|c|c|c|}
\hline 1 & 2 & 3 & 4 & 5 & 6 & 7 & 8 \\
\hline 10 & $\begin{array}{c}\text { Inflation rate (CPI, annual variation } \\
\text { in \%) }\end{array}$ & 0.5 & 24.9 & 43.3 & 12.4 & 13.7 & +1.3 \\
\hline 11 & Policy interest rate (\%) & 6.5 & 14.0 & 22.0 & 14.0 & 14.5 & +0.5 \\
\hline 12 & Exchange rate (USD) & 8.24 & 15.82 & 24.03 & 27.1 & 28.16 & +1.06 \\
\hline 13 & Current account balance (USD bn) & -16.5 & -4.6 & 1.6 & -1.3 & -2.1 & -0.8 \\
\hline 14 & Trade balance (USD bn) & -22.1 & -7.1 & -3.5 & -6.8 & -9.4 & +2.6 \\
\hline 15 & Exports (USD bn) & 59.1 & 50.6 & 35.4 & 33.6 & 39.7 & +6.1 \\
\hline 16 & Imports (USD bn) & 81.2 & 57.7 & 38.9 & 40.4 & 49.1 & +8.7 \\
\hline 17 & External debt (\% of GDP) & 79.0 & 96.4 & 136 & 124 & 103 & -21 \\
\hline
\end{tabular}

Looking at the breakdown, domestic demand was in the driver's seat in the second quarter. Government spending growth soared by double digits, swinging from a contraction at the outset of the year and marking the strongest increase since 2015. The second-quarter increase in public spending was primarily driven by the allotment of higher household utility subsidies. Household consumption growth, meanwhile, remained solid and came in at $4.2 \%$, against the backdrop of improving consumer sentiment, higher real wages, growing remittances and an increase in pensions. Lastly, amid a favorable business climate, fixed investment rose a solid $14.2 \%$ yoy, led by a marked increase in budget capital expenditure on road and transport infrastructure. Nevertheless, the rate of investment growth decelerated somewhat from the previous quarter.

The Central Bank expects real GDP growth to accelerate to $3.4 \%$ this year. Focus Economics panelists see GDP rising 3.2\% in 2018 and 3.1\% in 2019, which is unchanged from previous month's estimate.

The external sector's contribution to growth deteriorated in the second quarter, with exports of goods and services up $0.1 \%$ yoy, compared to a significant $9.9 \%$ contraction in the first quarter. The improvement came on the back of higher exports of foods, ores, and ferrous metals, and despite the drop in grain exports due to low yields of early crops. However, imports returned to growth, following the first contraction in two years observed in the previous quarter.

Looking ahead, the next tranche of financing under the USD 17.5 billion deal with the IMF remains up in the air after the Fund's mission in Ukraine that ran from 6 to 19 September 2018 concluded without reaching an agreement. Discussions are reportedly ongoing, with a deal for unlocking financial aid deemed by the Central Bank as critical to the country's macro-financial stability next year, when the election cycle kicks into full swing. Meanwhile, the country signed an EUR 1.0 billion loan agreement for the fourth EU macro-financial assistance program on 14 September 2018, with money destined to replenish Ukraine's international reserves.

Therefore, we considered the economic situation of the country's macroeconomic indicators. The situation is not easy, but according to some sources and economists, it is not very bad.

There is reason to be optimistic about Ukraine's economic future. The latest UBJ report cites a new production line from one of Ukraine's biggest food processing companies, 13 new gas wells in the Lviv region and the introduction of 
Ryanair flights to and from Ukraine as indicators of the country's improving economic situation.

It must be understood that the occupied areas are only three percent of the national territory. So, it's a very successful propaganda campaign by the Kremlin to tar all of Ukraine with the hostilities in the East, and, we're ignoring the other $97 \%$ of the country.

Growth in the foreign investment sector could also be on the horizon. While some foreign businesses may be "standoffish" about investing in Ukraine during an election year, the existing foreign investors in Ukraine are looking to expand [4].

In terms of Ukraine's relationship with western institutions, even Ukraine's Association Agreement with the European Union, which was finally ratified last year, is actually starting to pay off.

It is working slowly, but it will work faster. The European foreign minister came through here and said that probably a lot of the $2.5 \%$ growth last year was the locomotive of an increase of $27 \%$ in exports to the EU, and that pulled Ukraine forward.

Recently, more and more investors want to cooperate with Ukraine. However, there are a number of complexities.

The obstacle number one is obviously the lack of rule of law, where you can't trust the courts. And the foreign businessmen know that, and Ukrainian businessmen know even better. But, people can work around that to some degree.

The other thing is a little more subtle - it's just the general ignorance about Ukraine. People do not know Ukraine, they haven't been here. If we look at Mexico, which has many problems, 3\% of the entire US population went to Mexico last year on vacation. If 3\% of Germans came here, that would mean there'd be 2.4 million Germans in Ukraine.

The war is sometimes used as an excuse by the government for not making the reforms happen. At the same time, they are pointing to the war too much and that makes people not want to invest in Ukraine. It's the case that business ignores that fact and does what it likes in other regions.

The State Property Fund has posted on its website that 660 small-scale state companies are to be sold this year. At the same time, we know that the biggest state enterprises, which are probably the most difficult to be privatized, and that's the most difficult for the government to give it to somebody else, because these are the place where we really look at the most corrupt cases. Every single year, the government promises to sell these huge companies, but now we have other situation.

So, what are the trends in Ukrainian economy? Which are the most interesting sectors for somebody who is interested in doing business in Ukraine?

In our point of view, agriculture has tremendous growth ahead of it. Ukraine is going to help feed the world. It is very strong. What they've seen in American and German, and foreign businessmen here say they want to expand. The ones who are in Frankfurt and New York are toe-dipping and are standoffish about coming in, especially in an election year. But a survey of the American Chamber of Commerce, a survey of the German Chamber of Commerce, at least two thirds of the members are expanding, or are spending more money, in Ukraine now. They know 
Ukraine, they are here, they know the risks, they know how to operate here. It's the people outside that are, kind of, watching.

Throughout modern history Ukraine has been called the "bread basket of Europe". Today the country is frequently referred to as being a potential global agricultural superpower. Ukraine comes by this reputation justifiably, as its agricultural output is legendary.

By European standards Ukraine's land resources are enormous. Over $70 \%$ of the country's total area is agricultural land. This amounts to just over 42 million hectares of which 32 million is arable land suitable for grain and vegetable farming. In addition, Ukraine possesses a significant amount of rich fertile black soil known as "chornozem" representing $30 \%$ of the world's reserves.

These advantages are further leveraged by Ukraine's favorable geographic location which places it in a temperate continental climate zone with adequate access to water and transportation networks. The sector also benefits from the services of a highly skilled and large labor pool where approximately $25 \%$ of Ukraine's 44.5 million population is employed in the agricultural sector.

According to the forecast of a certain economic source we can see the forecasts for Ukraine including a long-term outlook for the next decades, plus medium-term expectations for the next four quarters and short-term market predictions for the next release affecting the Ukraine economy (table 2) [5].

\section{Table 2. Ukraine's Economic Forecasts}

\begin{tabular}{|c|c|c|c|c|c|c|c|}
\hline № & Indicator & Actual & Q4/18 & Q1/19 & Q2/19 & Q3/19 & 2020 \\
\hline 1 & Population, ml & 42.41 & 42.02 & 41.93 & 41.85 & 41.76 & 38.37 \\
\hline 2 & Wages, UAH/month & 8977.0 & 9000 & 8000 & 9166 & 9163 & 10000 \\
\hline 3 & Labor force participation rate, \% & 62.9 & 62.6 & 63.03 & 63.06 & 62.8 & 63.5 \\
\hline 4 & GDP growth rate, \% & 1,0 & 0.4 & 0.3 & 0.5 & 0.4 & 0.6 \\
\hline 5 & Unemployment rate, \% & 8.3 & 9.4 & 8.4 & 8.5 & 8.7 & 8.2 \\
\hline 6 & Inflation rate, \% & 8.9 & 8.9 & 6.5 & 6.3 & 6.0 & 5.2 \\
\hline 7 & Interest rate, \% & 18.0 & 18.0 & 17.5 & 17.0 & 17.0 & 15.0 \\
\hline 8 & Trade balance & -847.6 & -1130 & -480 & -400 & -931 & -830 \\
\hline 9 & Government debt, \% of GDP & 71.8 & 65.0 & 61.0 & 61.0 & 61.0 & 64.1 \\
\hline 10 & Industrial production, \% & -0.5 & 2.3 & 1.8 & 2.1 & 1.9 & 2.2 \\
\hline 11 & Manufacturing production, \% & -0.5 & 1.12 & 1.02 & 1.02 & 1.02 & 1.02 \\
\hline 12 & Competitiveness index, points & 57.03 & 4.11 & 4.11 & 4.11 & 4.11 & 4.11 \\
\hline
\end{tabular}

Therefore, as can be seen from the above, the population of the country will gradually decrease. However, there are a number of positive changes, namely: we have an increase in GDP, labor force, in manufacturing and industrial production.

We will add some attention to production as one of the sources of certain opportunities of the country. Ukraine has a large manufacturing base which historically was focused on heavy industry. In recent years, this sector has undergone changes and gradually diversified in response to market sector demands. The sector continues to be supported by an extensive network of polytechnic institutes, which annually graduate thousands of engineers across a wide range of disciplines. It's heavy industry - machine building, automotive, aviation, shipbuilding, light industry [6]. 
Also Ukraine's vast road, rail, air and sea infrastructure, together with the benefits of its geographic location, makes the country an important transit corridor for trade and travel between Europe, Asia and the Middle East. The transportation sector is the most developed and extensively utilized of all infrastructure assets. By European standards the transportation sector is a huge conglomerate which encompasses a diverse aggregate of railway networks, roads, seaports and airport facilities, together with their supporting services.

We want to admit, that Ukraine is taking important strides to increase the use of renewable-energy sources and alternative fuels as part of its broader strategy to reduce its reliance on traditional fossil fuels. It has been estimated that Ukraine has the potential to increase its use of renewable energy ten fold, by the year 2030 and reduce its natural gas consumption by $15 \%$ over the same period.

Energy efficiency and energy security are now operative words for companies and countries alike; going forward, renewable and alternative energy issues will only become more important.

The opportunities to invest in Ukraine's alternative energy sector are exceedingly favorable as the country has diverse reserves of raw material and a well educated workforce possessing the technical know-how required to develop and introduce the latest commercial advances in this sector. As a result, interest in Ukraine's renewable energy sector continues to grow and the government estimates that the total investment in alternative energy will reach 18 billion USD by the year 2020 .

\section{Conclusions}

So, as we have seen Ukraine has quite high potential for strengthening its economic positions. It is very important to understand that it is possible to achieve economic development only under the condition of competent management and allocation of resources of the country.

The existence of military processes in the country should not be a major threat to the economy, since the occupied part is about $3 \%$ of the country. Attracting most of the investment should be done through improving the investment climate, as well as the legislative framework of the Ukraine.

\section{References}

1. Ukrain`s reforms URL: http://ukrainetrek.com/about-ukraine-economy.

2. Economic growth of Ukraine URL: https://www.worldbank.org/en/news/press-release/2018/04/10/ukraine-economic-update-spring-2018.

3. Ukraine Economic Outlook URL: https://www.focus-economics.com/countries/ukraine.

4. Ukraine URL: https://en.hromadske.ua.

5. Ukraine - Economic Forecasts URL: https://tradingeconomics.com/ukraine/forecast.

6. Your Investment Matters URL: https://ukraineinvest.com/sectors/. 